\title{
norden
}

\section{Frá draumi til veruleika}

Norræn hæfnimarkmið og kennslufræðilegar áherslur í frumkvöðlamennt

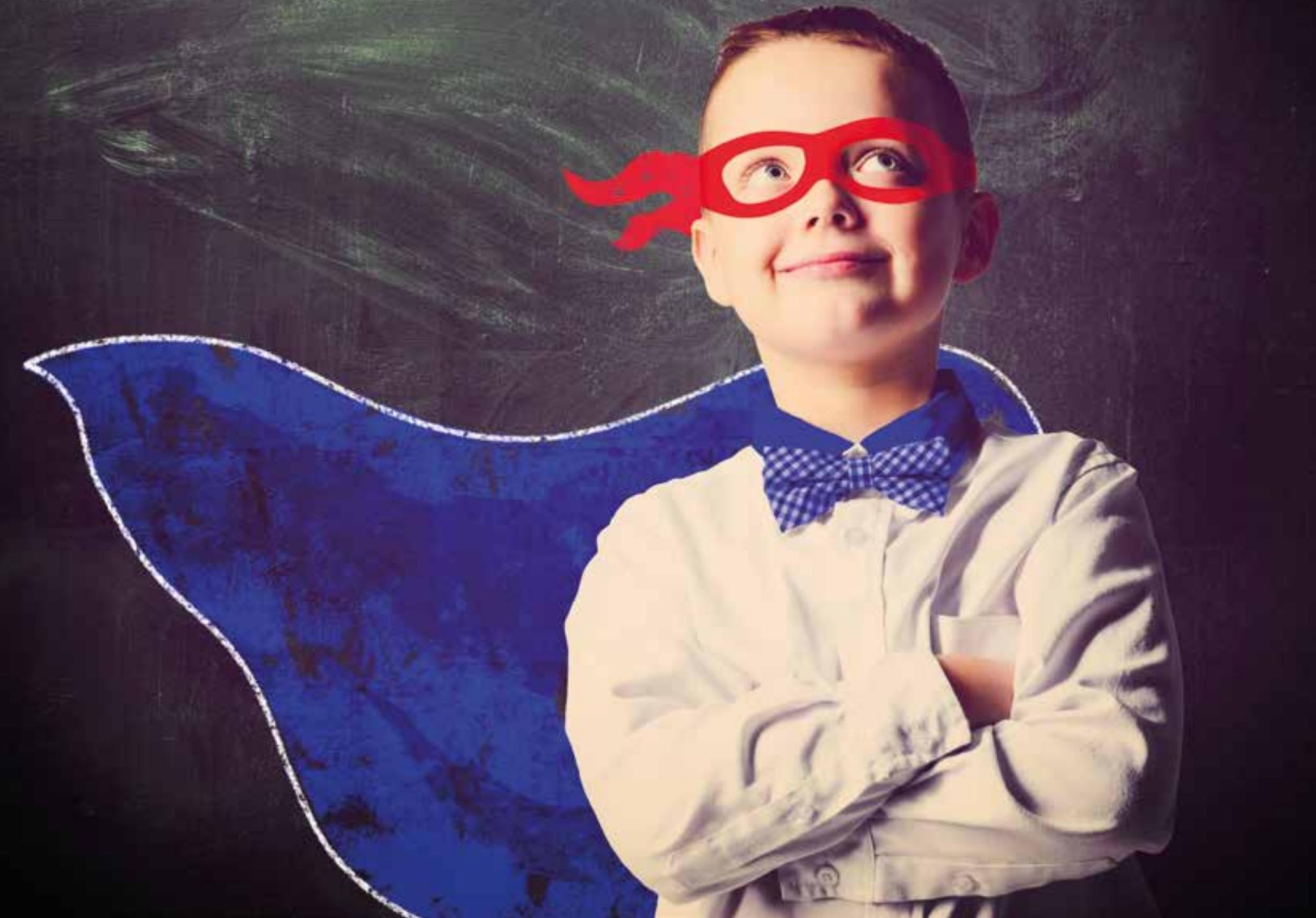




\section{Frá draumi til veruleika}

Norræn hæfnimarkmið og kennslufræðilegar áherslur í frumkvödlamennt

Anders Rasmussen og Anne Fritzner

ISBN 978-92-893-4488-3 (PRINT)

ISBN 978-92-893-4489-0 (PDF)

http://dx.doi.org/10.6027/ANP2016-713

ANP 2016:713

(C) Norræna ráðherranefndin 2016

Umbrot: Gitte Wejnold

Kápumynd: SignElements.com

Ljósmynd: SignElements.com

Printed in Denmark

Norræna rádherranefndin styrkti útgáfu skýrslunnar.

Efni skýrslunnar endurspeglar pó ekki endilega sjónarmið, álit, afstöðu eða meðmæli Norrænu rádherranefndarinnar.

www.norden.org/nordpub

\section{Norrænt samstarf}

Norræna samstarfið er eitt umfangsmesta svæðasamstarf í heiminum. Samstarfið nær til Danmerkur, Finnlands, Íslands, Noregs og Svípjódar auk Álandseyja, Færeyja og Grænlands.

Norræna samstarfið er pólitískt, efnahagslegt og menningarlegt og skiptir miklu í evrópsku og alpjódlegu samstarfi. Í norrænu

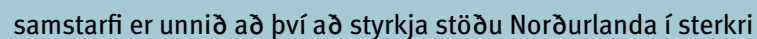
Evrópu.

Með norrænu samstarfi er unnið að pví að efla norræna og svæðisbundna hagsmuni í alpjóðlegu umhverfi. Sameiginleg

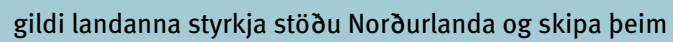
meðal peirra svæða í heiminum par sem nýsköpun og samkeppnishæfni er mest.

\section{Norræna ráðherranefndin}

Ved Stranden 18

DK-1061 København K

Telefon (+45) 33960200

www.norden.org 


\section{Frá draumi til veruleika}

Norræn hæfnimarkmið og kennslufræðilegar áherslur î frumkvöðlamennt 


\section{Formáli}

Norræna rádherranefndin hefur unnið í mörgum áföngum að eflingu menningar og menntunar frumkvöðla á Norðurlöndum. Hnattvæðing, tæknipróun, hraðar breytingar og lýðfræðilegar breytingar skapa áskoranir fyrir bæði norræna velferðarlíkanið og einstaklinga. Af peim sökum hefur í tímans rás komid fram pörf fyrir að menntakerfið geti undirbúið nemendur fyrir líf par sem peir geta verið virkir pátttakendur í mótun framtídar.

Verðlaunuð skýrsla Norrænu rádherranefndarinnar um frumkvöðlamennt á Norðurlöndum - "Entrepreneurship Education in the Nordic countries"1 - og skýrsla ESB um frumkvödlamennt - "Final Report of the Thematic Working Group on Entrepreneurship Education" ${ }^{2}$ - nefna pörfina á að próa hæfniramma sem getur byggt brú milli stefnu, stjórnunar, starfsvenja og náms. Um leid getur hæfnirammi skapað framvindu í kennslunni og varpad skýru ljósi á hver munurinn er á nemanda sem hefur tekið pátt í námi fyrir frumkvödla og nemanda sem hefur ekki tekið pátt. Hæfnirammi á ad gefa kost á aว kennslan taki mið af hvað eigi að læra fremur en af sérstöku starfi eða ferlum. Pessi hæfnirammi reynir að uppfylla pessa pörf með virðingu fyrir norrænum hefðum í skólamálum og fyrir skilningi á frumkvödlastarfi sem komið hefur upp samhliða á Norðurlöndunum. Í norrænu samhengi skólastarfs er frumkvödlastarfsemi ætlad að veita nemendum hæfni, sem má nota í mörgu samhengi, persónulega, félagslega og samfélagslega.

Hæfniramminn höfðar til fjölmargra hagsmunaadila: Hann er fyrst og fremst tæki fyrir kennara og starfsmenn sem geta fundið hæfni- og námsmarkmið sem og kennslufræðilegar áherslur fyrir kennsluna. Hæfniramminn höfðar líka til valdhafa, sem eiga að skapa löggjöf og umgjörd svo frumkvödlamennt geti farið fram. Á sama hátt höfðar hann til yfirmanna sem í daglegu starfi eiga að styðja uppbyggingu og skapa umhverfi og kennslufræðilega próun pannig að frumkvöдlamennt verði sampættur hluti grunnskólans.

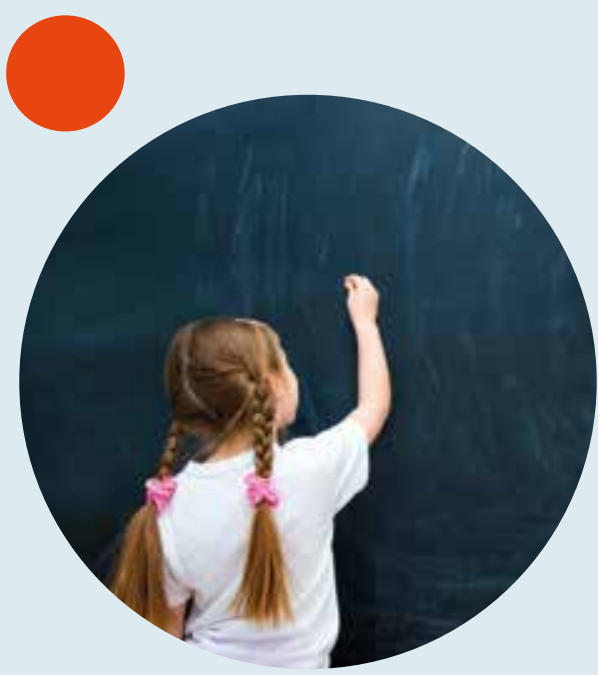




\section{Hið sérnorræna}

Prátt fyrir innbyrdis mun skóla á Norðurlöndum, pá eru líka fjölmörg sameiginleg einkenni. Petta vardar pýdingu menntunar sem hugtaks, áhrifa frá fræðslusamtökum alpýdu og umbótauppeldisfræðinni og nú sídast áherslu á albjódlegan samanburd og á kennslu á grundvelli gagnreyndra aðferða og námsmarkmiða.

\section{Menntun}

Menntunarhugtakið hefur frá upphafi opinberra skólakerfa verið hluti af norrænum hugsanagangi um skóla og menntun. Skilningur á menntun nær til pess ad til sé eitthvað sem nær út yfir fag og fagvitund og sem varðar hið ólokna ferli pess að verða gódur og gegn samfélagspegn í menningarlegu samhengi. Í norrænum skólum er hugsjóninni um menntun lýst í yfirmarkmiðum skólastarfsins. Menntun og menntahugsjónir eru pó ekki fastar stærðir og breytast yfir tíma á grundvelli breytilegs pólitísks og menningarlegs samhengis, sem og kennslufrædilegra og heimspekilegra strauma. Menntun er pannig lifandi hugtak, sem hefur sveiflast á milli áherslu á persónulegan vöxt og áherslu á ad tileinka sér fyrirfram ákveðin fagleg markmið. ${ }^{3}$

Norræn lýðræðis- og velferðarríki hafa pannig orðið til í nánu samspili lýðræðislegrar menntahugsjónar, par sem nemendur eiga aə læra að taka afstöðu, bregðast

${ }^{1}$ Norræna rádherranefndin (2012).

${ }^{2}$ Evrópusambandid (2015).

${ }^{3}$ Gustavsson (1998) Dannelse i vor tid, Forlaget KLIM. 


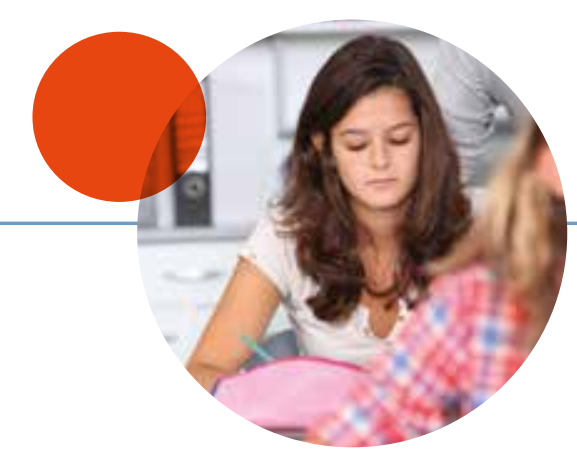

við, leggja sitt af mörkum til lýðræðislegs samfélags og starfa sem borgarar í lýðræðissamfélagi. Hluti menntunarhugtaksins varðar hæfni til sjálfsákvörðunar, félagslegrar ábyrgðar og hæfileikans til að taka pátt í að̀ skapa nýtt samfélag. Pessi skilningur fellur pétt að norrænni frumkvöəlamenntun og umræddum hæfniramma. Menntunarhugtakið er flókið vegna ólíks skilnings á hugtakinu og vegna pess aə pað birtist oft sem andstæða við fagmennsku, prátt fyrir að fagmennska hafi ávallt verið hluti menntunar. Par à auki er oft óljóst hvað pad er sem læra skal og tileinka sér til að teljast vera „menntaður“. Pessi hæfnirammi er tilraun til að fastmóta og leysa úr læðingi suma peirra menntunarpátta frumkvödlastarfs sem pegar má finna í markmiðum skólanna.

\section{Kennslufræðilegar umbætur}

Kennslufræðilegar umbætur hafa haft mikil áhrif á norrænar hugmyndir um menntamál og haft í för með sér að skóli valdboðs með hörðum aga og utanbókarlærdómi er horfinn. Hvað sem núverandi áherslu á fagmennsku og mælanleika lídur, snýst kennslan enn um barnið og tekur oftast nær mið af pörfum og áhugamálum nemenda. Sömuleiðis er virk pátttaka nemenda í náminu í verkefna-, hóp- og pverfaglegu starfi hluti af daglegu norrænu skólastarfi. Ásamt fræðslusamtökum alpýðunnar hefur petta gefið ákveðna norræna „hversdagslega speki“ sem pýðir aə pað eru óformleg og jafngild tengsl milli kennara og nemanda og að komið er til móts við áhugahvöt nemenda, áhuga og áhugamál í kennslunni. ${ }^{4}$
Á almennum nótum hefur hin frelsandi og umbótavæna venja unnið „fjandakornið hafi pað“, vandinn í dag er pannig ekki pad „ófrelsi“ sem hin frelsandi kennslufræði átti að ráda bót á, heldur til hvers við eigum að nota frelsi og frelsun. ${ }^{5}$ Frumkvödlamennt má líta á sem frekari próun á hugmyndum um kennslufræðilegar umbætur, par sem hún stefnir á ad styðja við möguleika nemenda á ad taka pátt í samfélaginu, ad stjórna eigin lífi og starfsframa og að geta hrint hlutum í framkvæmd sem hafa pýðingu fyrir aðra, menningarlega, fjárhagslega og félagslega. ${ }^{6}$ Frumkvödlamennt er pannig ekki frelsandi í hefəbundnum skilningi, heldur beinist að pví að efla hæfni nemandans í ad nota pá möguleika, sem lífid og heimurinn hafa upp á à bjóda.

\section{Áhersla á námsmarkmið̀ og námsmat}

Á sídastliðnum árum eru mælanlegar faglegar niðurstöður og alpjóðlegur samanburður orðin hluti af pólitískri skóladagskrá og par með einnig af daglegu norrænu skólastarfi. Um leið hafa rannsóknir, sem sýna að nemendur læra meira ef kennslan er byggðá sýnilegum námsmarkmiðum og á svörun, haft mikil áhrif. ${ }^{7}$ Á heildina hefur petta gefið tilefni til nokkurra umbóta á skólakerfum og peim kröfum sem gerdar eru til skóla og kennara. Próunin hefur átt sér stað samhliða innleiðingu á stefnunni um frumkvöðlastarf. Vandamálið er að pegar námsgreinar skólans eru í auknum mæli flokkaðar niður og mældar, pá er hætta á að yfirmarkmið skólans, par á meðal frumkvödlapættir, birtist sem óljósir og óviðrádanlegir. Pví er pessi hæfnirammi tilraun til að skilgreina námsmarkmið fyrir frumkvöəlamennt 
pannig ad hægt sé ad nota pau í kennslu, svörun og mati til jafns við námsgreinar skólans. Hæfniramminn gerir kleift ad leggja áherslu á hæfni og námsmarkmið í stadinn fyrir ólíkan skilning á ferlum, nálgun við kennslu og starfsvenjur. Frumkvöðlamennt verður pannig mjög einföld:

\section{„Sú menntun sem styəur við próun úrræəa fyrir frumkvöəla, hæfni og reynslu. “}

Lykilatridi í pví samhengi er ad skólarnir geti veitt nemendum ákvedna hæfni, en hvernig nemendur kjósa að nota pessa hæfni pegar fram í sækir er alfarið undir peim sjálfum komið. Pess vegna er pað ekki ætlunin

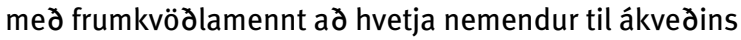
lífsstíls, sérstaks vals á starfsgrein eda sértækum leiðum til ad taka pátt í samfélaginu.

${ }^{4}$ Hammershøj (2012) Kreativitet - et spørgsmål om dannelse, Hans Reitzels Forlag.

${ }^{5}$ Ziehe (2004) Øer af intensitet $i$ et hav af rutine, Nye tekster om ungdom, skole og kultur, Forlaget Politisk Revy.

${ }^{6}$ Rasmussen, Revsbeck, Moberg (2015) Taksonomi for entreprenørskabsuddannelse, Fonden for Entreprenørskab.

${ }^{7}$ Hattie (2009) Visible Learning, Routledge.

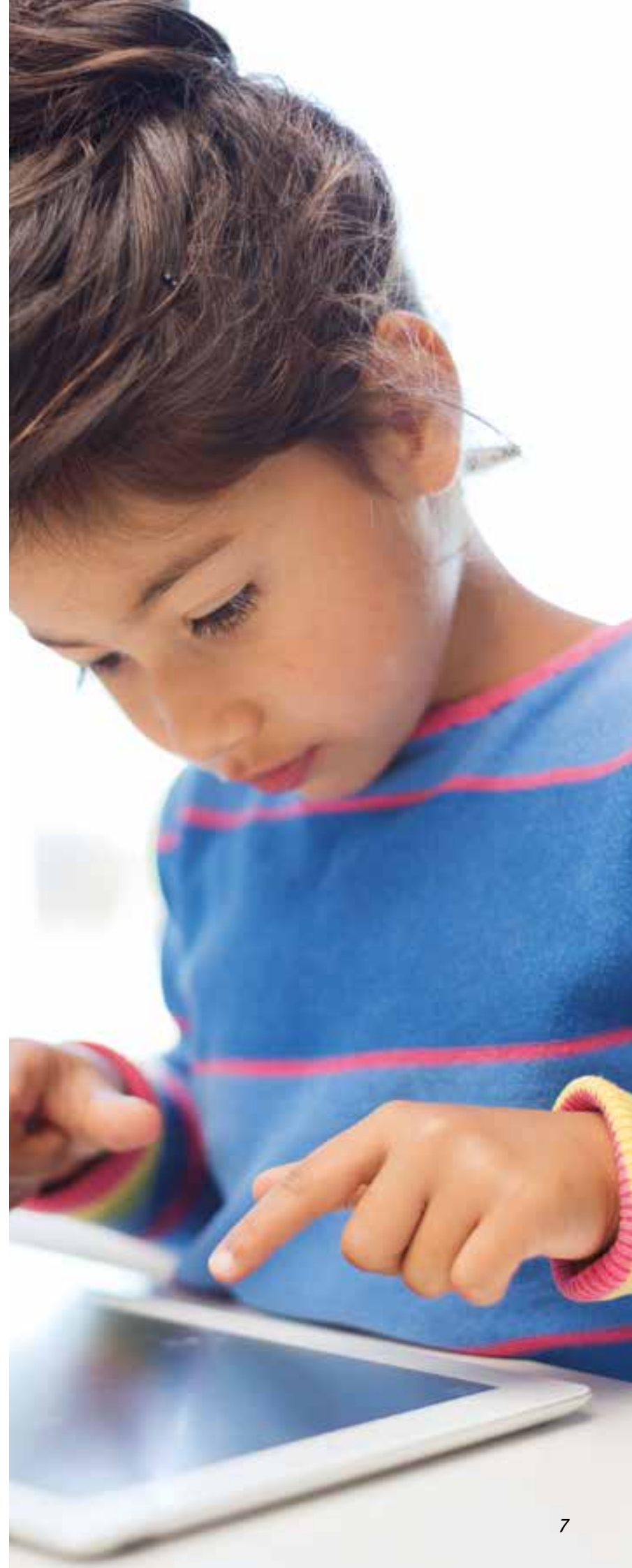




\section{Frumkvödlahæfni}

Hæfniramminn byggir á aðgengilegum alpjóðlegum rannsóknum og á norrænum skólamarkmiðum og stefnum í frumkvöдlastarfi. Viðmiðunarhópur frá Norðurlöndunum fimm og sjálfstjórnarsvæðunum premur tók bátt til à tryggja ad nota megi rammann á hverjum stað fyrir sig. Hæfnihugtakið er undir áhrifum frá Illeris ${ }^{8}$ og ber à̀ skilja sem:

\section{„Heildstæдa skynsemis- og tilfinningalega tengda hæfni, rádstafanir og möguleika, sem tengjast hugsanlegum athafnasvidum og er hrint í

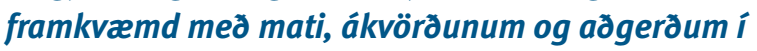 tengslum við pekktar og ópekktar aðstæður.“}

Ramminn er pannig mótaður sem ólík hæfni, sem er byggdá pekkingu, leikni, tilfinningum og persónulegum úrrædum.
Pekking og leikni eru ad̀ grunni til skýr og pó peir pættir séu ekki alltaf mælanlegir, pá er hægt að fylgjast með peim og beita kerfisbundinni flokkun. Hins vegar háttar til á annan hátt með persónulegu og hlutlægu úrræðin, sem ekki er hægt að kenna, prófa og meta. Til dæmis er pað líkast til mikilvægt úrrædi „,að vera prautseigur“,

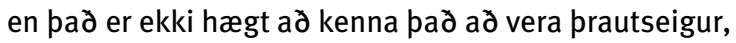
heldur verður að æfa prautseigju með peim aðferðum og leiðum, sem beitt er í kennslu. Pess vegna varðar pessi hluti hæfnirammans meira aðferðir og kennslufræðilega nálgun en hin skilmerkilegri pekkingar- og hæfnisvið.

\section{Rannsóknir}

Fræðilega séd ríkir ekki samstada um hvaða pekking, hvada leikni og persónuleg úrræði fela í sér frumkvöðlahæfni. Sömuleiðis ríkir ekki samstaða um hvernig byggja skuli upp pessa hæfni. Pó eru til

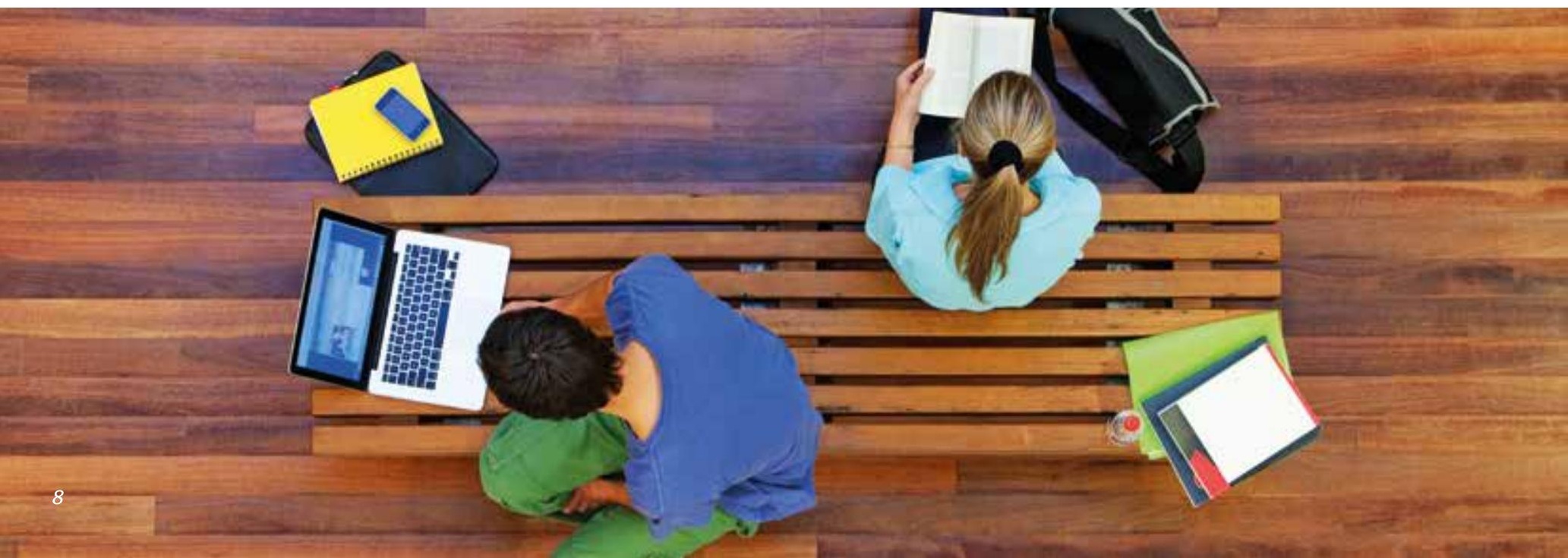




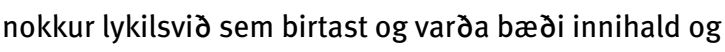

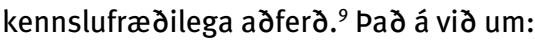

- Áherslan á athafnapáttinn og að frumkvöðlamennt skuli vera byggd á beinu starfi nemenda og virkri pátttöku peirra.

- Sköpunargledi og hæfileikinn til ad sjá, skynja og skapa möguleika sem og hæfileikinn til à leysa vandamál, fjölbreytt hugsun og ad geta gert tilraunir med ólík pekkingarform.

- Pekking á, skilningur á og samspilid vid menningu, umhverfid og utanadkomandi adila.

- Hlutlæg trú nemendanna og sjálfstraust varðandi eigin möguleika og úrræði til að geta tekið pátt í samfélaginu og látið drauma og vonir rætast, par med talið prautseigju og hæfileikann til að bregðast við óvissu.

\section{Norrænar stefnur og menntunarmarkmið}

Í yfirmarkmiðum Norðurlandanna í skólamálum og í stefnu landanna um frumkvödlastarf koma mörg pekkingar-, leikni- og hæfnimarkmið við sögu, sem beint eða óbeint tengjast frumkvöðlastarfi. Sum sviðanna varða ytri pætti sem nemendur eiga að pekkja til: „skapandi vinnuaðferðir, viðskiptapróun, fjármál, verkefnastjórnun, tengslanet”, og hluti sem peir eiga að geta ráðið við: „tekið frumkvæði, ábyrgð, breytt hugmyndum i framkvæmd, ákvardanataka, samskipti, samstarf og lausn vandamála”. Önnur svið varða innri pætti og par með tilfinningalega og persónulega tengd úrræði eins og til dæmis: „Taka opna afstödu til möguleika, prautseigju og seiglu, forvitni, sjálfstrausts, sköpunargledi og pors til að taka áhættu, nota hugmyndaflug til að fara út fyrir núverandi mörk". Fyrir utan petta eru nokkrar staðlaðar eða siðferðislegar

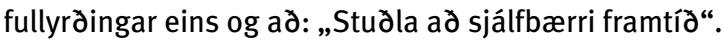

\section{Framlag viðmiðunarhópsins}

Viðmiðunarhópurinn setti fram fjölmargar hugmyndir sem varda pekkingu, leikni og hæfni. Eins og í helstu markmiðslýsingum skólastarfsins er hér líka um að̀ ræða mjög fjölbreytileg pekkingar-, leikni- og hæfnimarkmið, sem varða bæði ytri og innri pætti eins og til dæmis: „Ég sem frumkvöðull, hvernig samfélagið er uppbyggt og virkar, kynna sjálfan mig og hugmyndir mínar, sjá parfir og finna lausnir, taka á skapandi hátt á óvissu, greina möguleika og vera virkur, pekking á nánasta umhverfi, landinu og heiminum".

í ljós kemur einnig breytileg áhersla á „framvindu og kerfisbundna flokkun“ (DK), sérstök mynd

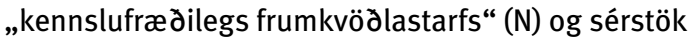
nálgun vid „frumkvöðlamenntun“(S). Hin ólíka nálgun sýnir að tiltölulega einsleitar stefnur Norðurlandanna hafa leitt til mikillar fjölbreytni î starfsemi og starfsháttum.

${ }^{8}$ Illeris (2013) Kompetence - Hvad, hvorfor, hvordan?, Samfundslitteratur.

${ }^{9}$ Nybye \& Rasmussen (2013) Progressionsmodel for innovations-og entreprenørskabsundervisning, Fonden for Entreprenørskab. 


\section{Hæfnirammi}

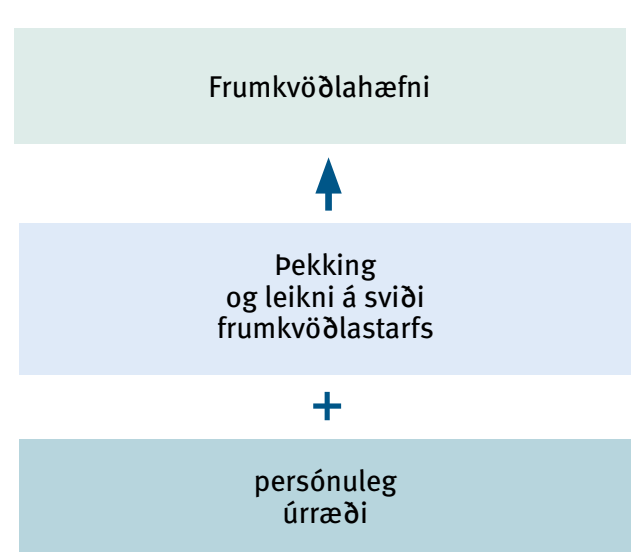

Með pví að taka saman ólík gögn og niðurstöður úr rannsóknum, norrænum skólamarkmiðum og frá viðmiðunarhópnum, kemur fram ferns konar hæfni, par af má byggja prennt á pekkingu og leikni. Fjórda sviðið varðar persónuleg úrræði og virkar sem grunnur til að hin prjú sviðin geti látið til sín taka. Til pess ad geta framkvæmt athafnir í samfélaginu parf hugrekki til, ábyrgð, viðurkenningu á mistökum o.s.frv. Á hinn bóginn munu persónuleg úrræði ein og sér ekki leiða til gódra athafna eða til frumkvöðlahæfni og menntunar.

1. Athafnahæfni: Skipuleggja, móta, framkvæma, eiga samstarf, eiga samskipti og hafa stjórn á fjármálum og úrræðum.

2. Sköpunarhæfni: Að skapa, fara fram úr, hugsa öðru vísi, hugsa pvert á hlutina, setja upp drauma, skynja, gera tilraunir, leysa vandamál og meta.
3. Skilningur á umheiminum: Pekking um menningarform, hnattvæðingu, skipan samfélagsins, viðskiptaskilning, félagslegar aðstæður, tengslanet, hæfileikann til að skilja og spjara sig i flóknum samtíma. Aəferðirnar við að skynja heiminn og umhverfi okkar, pær hugmyndir sem við erum opin fyrir.

4. Persónuleg úrræði: Hugrekki, sjálfstraust, prautseigja, úrlausn flókinna viðfangsefna og óvissu, viðurkenning á mistökum, frumkvæði, ábyrgð og sjálfstæði.

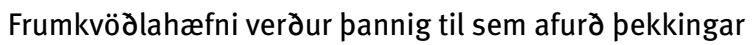
og leikni á sviði athafnasemi, sköpunargleði og umhverfis, meðákveðin persónuleg úrræði sem forsendu.

Hæfniramminn er útbúinn á premur stigum: 4. bekkjarstig/fyrstu skólaár grunnskóla, 7. bekkjarstig/ millistigið og 10. bekkjarstig/sídustu skólaár grunnskóla. Pekking, leikni og hæfni er á öllum premur stigum til marks um ákjósanlegasta möguleika og lokamarkmid. 


\section{4. bekkur}

\begin{tabular}{|c|c|c|c|c|c|}
\hline \multicolumn{2}{|c|}{$\begin{array}{l}\text { Athafnahæfni } \\
\text { Nemandinn getur átt samstarf um } \\
\text { verkefni og leyst einföld verkefni med } \\
\text { adstod í skólanum og næsta nágrenni }\end{array}$} & \multicolumn{2}{|c|}{ 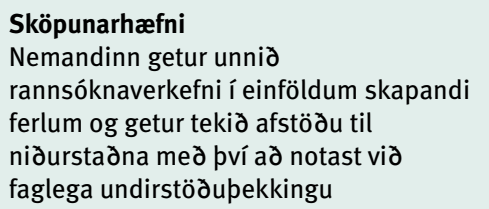 } & \multicolumn{2}{|c|}{$\begin{array}{l}\text { Skilningur á umheiminum } \\
\text { Nemandinn hefur fyrsta skilning á } \\
\text { eigin sjálfsmynd og menningarlegum } \\
\text { bakgrunni og getur ratad í einföldu } \\
\text { umhverfi á heimaslódum }\end{array}$} \\
\hline Leikni, getur & pekking á & Leikni, getur & Pekking á & Leikni, getur & Pekking á \\
\hline 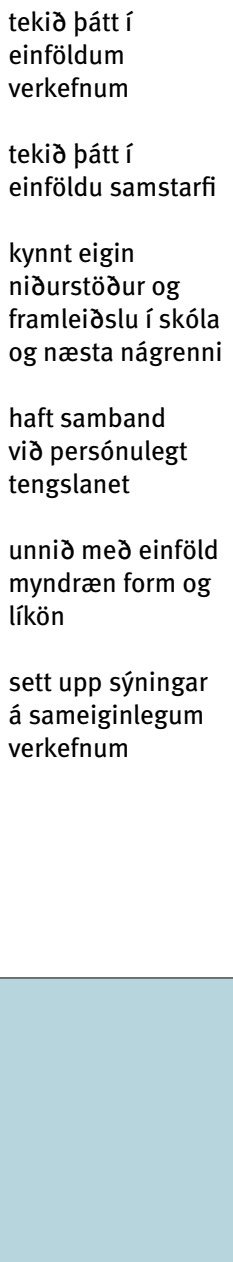 & $\begin{array}{l}\text { skipulagningu og } \\
\text { markmiðum } \\
\text { vinnu med ödrum } \\
\text { samskiptum } \\
\text { og einföldum } \\
\text { kynningar- } \\
\text { adferdum } \\
\text { persónulegu } \\
\text { tengslaneti } \\
\text { framsetningu } \\
\text { efnis og líkönum }\end{array}$ & $\begin{array}{l}\text { notad } \\
\text { hugmyndaflug og } \\
\text { sköpunargledi i } \\
\text { tengslum vid nám } \\
\text { og starf } \\
\text { tengt ólík } \\
\text { pekkingarsvid } \\
\text { leikid med } \\
\text { pekkingu } \\
\text { tekid pátt í } \\
\text { einföldum } \\
\text { ferlum par sem } \\
\text { hugmyndir verda } \\
\text { til } \\
\text { tekið pátt í } \\
\text { samtölum um mat } \\
\text { á hugmyndum } \\
\text { notad } \\
\text { tilfinningaleg } \\
\text { hugtök og } \\
\text { myndmál }\end{array}$ & $\begin{array}{l}\text { hugmyndaflugi og } \\
\text { sköpunarkrafti } \\
\text { einföldu } \\
\text { skapandi ferli } \\
\text { einfaldri sköpun } \\
\text { hugmynda } \\
\text { munaði og } \\
\text { einfaldri } \\
\text { fagurfræði }\end{array}$ & $\begin{array}{l}\text { lýst eigin } \\
\text { menningu } \\
\text { notad } \\
\text { peningahugtakið } \\
\text { vid einfaldan } \\
\text { útreikning } \\
\text { átt samtöl um } \\
\text { möguleika og } \\
\text { áskoranir í } \\
\text { nánasta umhverfi }\end{array}$ & $\begin{array}{l}\text { eigin menningu } \\
\text { og annarra } \\
\text { hugtakinu } \\
\text { peningar } \\
\text { vinnu- og } \\
\text { frístundalífi } \\
\text { fyrirtækjum og } \\
\text { stofnunum í } \\
\text { nánasta umhverfi }\end{array}$ \\
\hline
\end{tabular}




\section{7. bekkur}

\begin{tabular}{|c|c|c|c|c|c|}
\hline \multicolumn{2}{|c|}{$\begin{array}{l}\text { Athafnahæfni } \\
\text { Nemandinn getur í samstarfi við aðra } \\
\text { tekið frumkvæði, skipulagt, sett upp og } \\
\text { leyst einföld verkefni í ákveðnu samhengi }\end{array}$} & \multicolumn{2}{|c|}{$\begin{array}{l}\text { Sköpunarhæfni } \\
\text { Nemandinn getur unnið sjálfstætt, með } \\
\text { tilraunum og könnun í skapandi ferli } \\
\text { og metið niðurstöðurnar á grundvelli } \\
\text { faglegrar pekkingar og fagurfræðilegra } \\
\text { viðmiða }\end{array}$} & \multicolumn{2}{|c|}{$\begin{array}{l}\text { Skilningur á umheiminum } \\
\text { Nemandinn getur á grundvelli skilnings } \\
\text { á eigin sjálfsmynd og menningarlegum } \\
\text { bakgrunni ratad í ólíku tæknilegu, efna- } \\
\text { hagslegu, menningarlegu og félagslegu } \\
\text { samhengi }\end{array}$} \\
\hline Leikni, getur & Pekking á & Leikni, getur & Pekking á & Leikni, getur & Pekking á \\
\hline $\begin{array}{l}\text { lýst óvissu í } \\
\text { tengslum við } \\
\text { verkefni } \\
\text { tekið virkan pátt í } \\
\text { verkefnum } \\
\text { notad persónulegt } \\
\text { tengslanet } \\
\text { tekið pátt í } \\
\text { samstarfi } \\
\text { kynnt niðurstöður } \\
\text { og verkefni } \\
\\
\text { miðlad pekkingu } \\
\text { með líkönum, } \\
\text { skissum og } \\
\text { myndrænni } \\
\text { tjáningu }\end{array}$ & $\begin{array}{l}\text { einfaldri } \\
\text { verkefnastýringu, } \\
\text { skipulagningu, } \\
\text { áhættupáttum og } \\
\text { úrræðum } \\
\text { einföldum } \\
\text { samstarfs- } \\
\text { aðferdum } \\
\text { samskiptum, } \\
\text { kynningar- } \\
\text { aðferdum og } \\
\text { verkfærum } \\
\text { persónulegu } \\
\text { og skólatengdu } \\
\text { tengslaneti } \\
\text { líkönum, táknum } \\
\text { og myndrænni } \\
\text { tjáningu }\end{array}$ & $\begin{array}{l}\text { tengt fagleg } \\
\text { pekkingarsvið } \\
\text { gert tilraunir med } \\
\text { pekkingu } \\
\text { tekið pátt í } \\
\text { faglegri lausn } \\
\text { vandamála } \\
\text { unnið í skapandi } \\
\text { ferli } \\
\text { tekið pátt í } \\
\text { sköpun hugmynda } \\
\text { átt samtöl um mat } \\
\text { á hugmyndum } \\
\text { notad } \\
\text { tilfinningaleg } \\
\text { hugtök } \\
\text { rætt drauma um } \\
\text { næstu framtíð }\end{array}$ & $\begin{array}{l}\text { hugmyndaflugi } \\
\text { og sköpunargleði } \\
\text { tengdri ólíkum } \\
\text { fagsviðum } \\
\text { skapandi ferli } \\
\text { hnignunarferli } \\
\text { munaði og } \\
\text { fagurfræði }\end{array}$ & $\begin{array}{l}\text { borid saman } \\
\text { menningarheima } \\
\text { átt samtöl um } \\
\text { möguleika og } \\
\text { vandamál í } \\
\text { heiminum } \\
\text { rætt eigin skilning } \\
\text { á heiminum } \\
\text { sett upp einfaldar } \\
\text { fjárhagsáætlanir } \\
\text { lýst efnahag og } \\
\text { ödrum úrræðum í } \\
\text { samfélaginu } \\
\text { lýst hvernig } \\
\text { fyrirtæki starfar }\end{array}$ & $\begin{array}{l}\text { mun á menningar- } \\
\text { heimum } \\
\text { uppbyggingu } \\
\text { og skipan } \\
\text { samfélagsins } \\
\text { fjármálum og } \\
\text { ólíkum úrræðum } \\
\text { skóla-, vinnu- og } \\
\text { frístundalífi } \\
\text { fyrirtækjum og } \\
\text { stofnunum á } \\
\text { heimaslódum }\end{array}$ \\
\hline & $\begin{array}{r}\text { Hugr } \\
\text { Vilji til bre } \\
\text { Viðu } \\
\text { Getur }\end{array}$ & $\begin{array}{l}\text { PERSÓNU } \\
\text { og vilji til ad láta re } \\
\text { Ábyrgd á eigin ve } \\
\text { Sjálfstraust á gr } \\
\text { Tekur frumkv } \\
\text { gga á eigin vinnuad } \\
\text { Prautseigja og se } \\
\text { nning á eigin og ann } \\
\text { Polir óöryggi u } \\
\text { eeitt sér ad verkefnı }\end{array}$ & $\begin{array}{l}\text { Z ÚRRAEI } \\
\text { á sjálfan sig og fél } \\
\text { fnum og annarra. } \\
\text { Ivelli eigin getu. } \\
\text { med ödrum. } \\
\text { um, skoðunum og } \\
\text { um langan tíma. } \\
\text { a mistökum og miss } \\
\text { kamman tíma. } \\
\text { g áskorunum á lön }\end{array}$ & $\begin{array}{l}\text { sína. } \\
\text { armiðum. } \\
\text { ingi. } \\
\text { tíma. }\end{array}$ & \\
\hline
\end{tabular}




\section{0. bekkur}

\begin{tabular}{|c|c|c|c|c|c|}
\hline \multicolumn{2}{|c|}{$\begin{array}{l}\text { Athafnahæfni } \\
\text { Nemandinn getur í samstarfi við aðra } \\
\text { tekið frumkvæði og skipulagt, tekið } \\
\text { ábyrgð á, stjórnað, sett upp og leyst } \\
\text { verkefni í ákveðnu samhengi }\end{array}$} & \multicolumn{2}{|c|}{$\begin{array}{l}\text { Sköpunarhæfni } \\
\text { Nemandinn getur unnið sjálfstætt af } \\
\text { prautseigju, með tilraunum og könnun í } \\
\text { skapandi ferli og metið niðurstöðurnar á } \\
\text { grundvelli faglegrar pekkingar, reynslu og } \\
\text { fagurfræðilegra viðmiða }\end{array}$} & \multicolumn{2}{|c|}{$\begin{array}{l}\text { Skilningur á umheiminum } \\
\text { Nemandinn getur á grundvelli skilnings } \\
\text { á eigin sjálfsmynd og menningarlegum } \\
\text { bakgrunni ratad í og metið tæknilegt, } \\
\text { efnahagslegt, menningarlegt og } \\
\text { félagslegt samhengi }\end{array}$} \\
\hline Leikni, getur & Pekking á & Leikni, getur & Pekking á & Leikni, getur & Pekking á \\
\hline 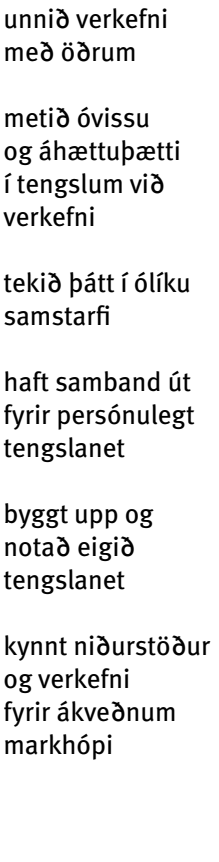 & $\begin{array}{l}\text { verkefna- } \\
\text { stýringu, } \\
\text { skipulagningu, } \\
\text { hagsmuna- } \\
\text { aðilum, } \\
\text { áhættubáttum } \\
\text { og úrræðum } \\
\text { samstarfs- } \\
\text { aðferðum og } \\
\text { ferli } \\
\text { persónulegu } \\
\text { og faglegu } \\
\text { tengslaneti } \\
\text { samskiptum, } \\
\text { kynningar- } \\
\text { aðferðum og } \\
\text { verkfærum }\end{array}$ & $\begin{array}{l}\text { tengt ólík fagleg } \\
\text { pekkingarsvið } \\
\text { gert tilraunir } \\
\text { af pekkingu og } \\
\text { fagmennsku } \\
\text { unnið med } \\
\text { faglegar lausnir á } \\
\text { vandamálum } \\
\text { komið skipulagi á } \\
\text { hugmynda-sköpun } \\
\text { unnið í ólíku } \\
\text { skapandi ferli } \\
\text { rætt mat á } \\
\text { hugmyndum } \\
\text { notað tilfinningaleg } \\
\text { hugtök í tengslum } \\
\text { vid faglega pekkingu } \\
\text { sett fram drauma og } \\
\text { framtíðarsýnir }\end{array}$ & $\begin{array}{l}\text { hugmyndaflugi og } \\
\text { sköpunargleði i } \\
\text { samfélaginu } \\
\text { skapandi ferli } \\
\text { ólíkum myndum } \\
\text { hugmynda- } \\
\text { sköpunar } \\
\text { munaði og } \\
\text { fagurfræði } \\
\text { sköpunargleði } \\
\text { í tengslum við } \\
\text { fagmennsku }\end{array}$ & $\begin{array}{l}\text { lýst og borið } \\
\text { saman } \\
\text { menningarheima } \\
\text { lýst möguleikum } \\
\text { og vandamálum } \\
\text { tengdum } \\
\text { hnattvæðingu } \\
\text { sett upp einfaldar } \\
\text { fjárhagsáætlanir } \\
\text { og bókhald } \\
\text { greint og lýst } \\
\text { úrræðum } \\
\text { lýst einföldum } \\
\text { viðskiptalíkönum } \\
\text { sett } \\
\text { spurningamerki } \\
\text { við núverandi } \\
\text { skilning á } \\
\text { heiminum }\end{array}$ & 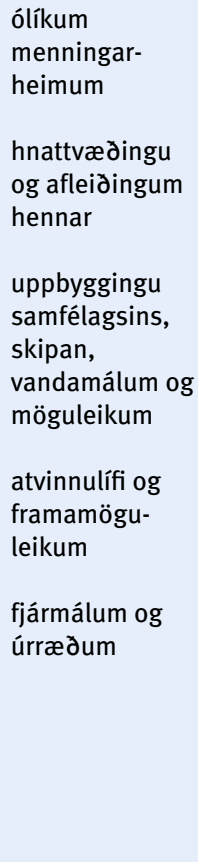 \\
\hline & Viðu & 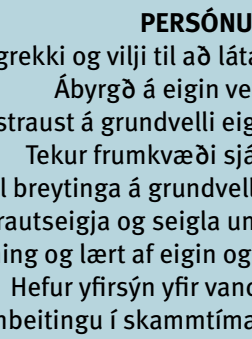 & $\begin{array}{l}\text { ÚRRAEI } \\
\text { yna á sjálfan sig og } \\
\text { num og annarra. } \\
\text { nats á getu og hæfil } \\
\text { ætt og med ödrum. } \\
\text { iverandi skilnings o } \\
\text { ngan og slitróttan tí } \\
\text { larra mistökum og n } \\
\text { jm og flókin verkefn } \\
\text { kefnum og langtíma }\end{array}$ & $\begin{array}{l}\text { a. } \\
\text { um. } \\
\text { kefnum. }\end{array}$ & \\
\hline
\end{tabular}




\section{Frumkvöðlahæfni î kennslufræðilegu samhengi}

Frumkvödlamennt er ekki námsgrein í norrænum skólum og frumkvödlahæfni parf pví ad byggja upp sem hluta af núverandi námsgreinum og sem sérstök námsferli i frumkvödlamenntun. Pað pýdir à kennarar verða að̀ geta sampætt námsgreinar skólans og próun

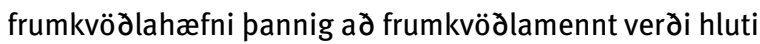
af daglegu skólastarfi. Um leið verða skólarnir að tryggja à̀ nemendum gefist færi á ad taka pátt í samfelldu frumkvöəlaferli par sem reynir á hæfnina, gjarnan í gagnlegu starfi.

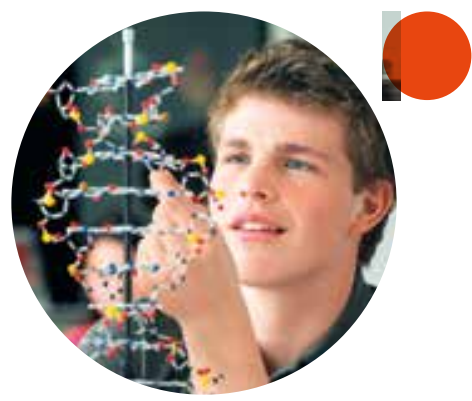




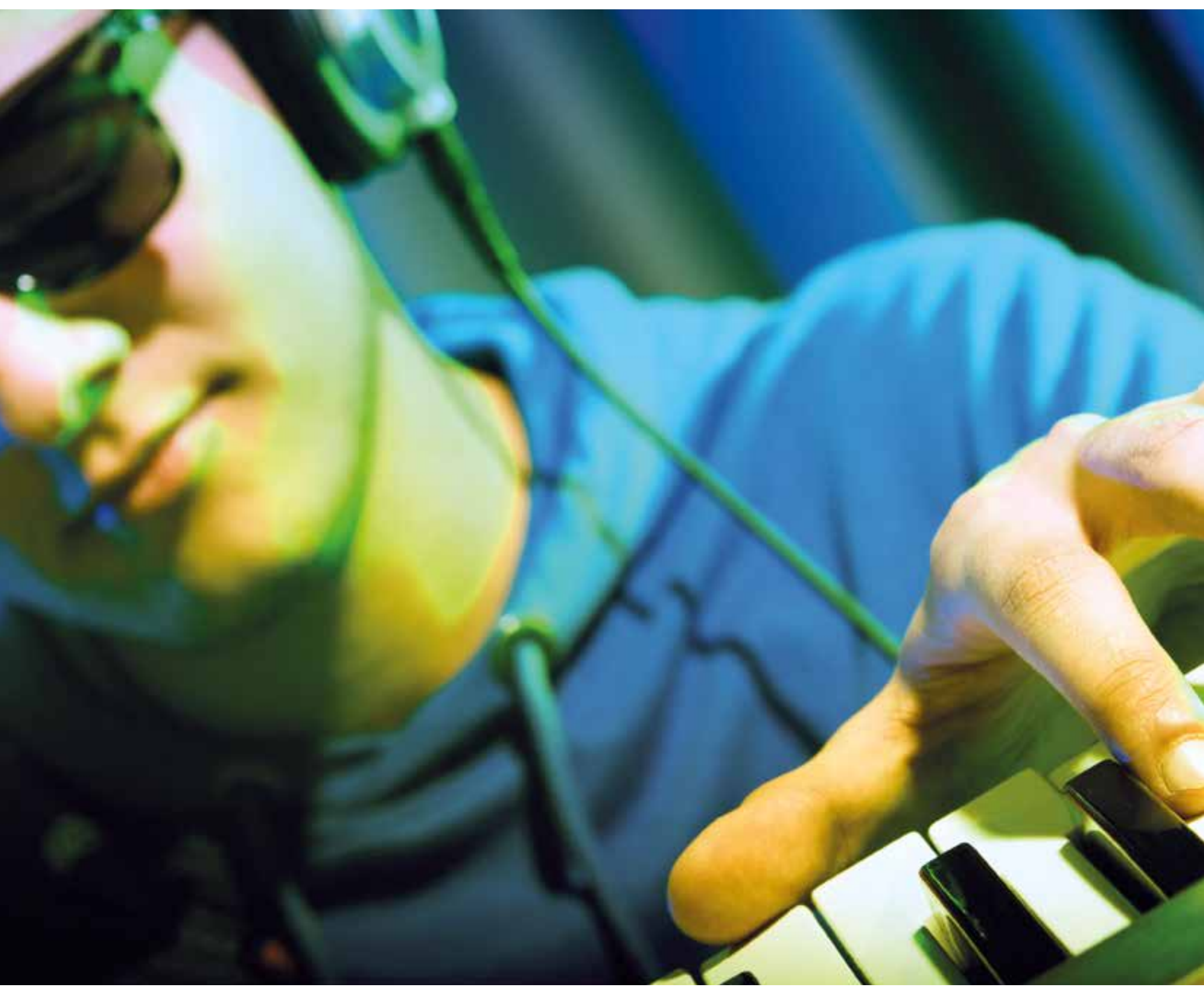




\section{Kennslufræðilegar áherslur}

Hér á eftir eru taldar upp nokkrar kennslufræðilegar áherslur sem geta stutt við aukna hæfni nemenda og aukin persónuleg úrræði peirra. Kennslufræði varðar samhengið milli markmiða kennslunnar, innihalds og aðferðar og eykur líkurnar á að̃ nemendur læri pað sem ætlast er til og styður um leið við frekari próun og nám nemenda. Kennslufræðilegar áherslur eru pannig tæki fyrir skipulagningu kennara á kennslu og hafa áhrif á form kennslunnar, skipulag og framkvæmd. Hugmyndin að baki áherslunum er að pær séu óhádar bekkjarstigi, getustigi og faglegu samhengi og að pær geti auðveldad yfirfærsluna úr hæfnimarkmiðum í framkvæmd og öfugt. Áherslurnar er hægt að taka í notkun eina í einu eða margar í einu, en líklega er ekki hentugt eða mögulegt aə̀ nota allar áherslurnar í einu.

\section{Áherslur sem styðja aukna athafnahæfni}

- Aə vinna með verðmætasköpun ${ }^{10} /$ störf sem breyta.

- Að vinna með pátttöku og aðild nemenda.

- Ad láta nemendur bera ábyrgdá starfi.

- Aà nota pekkingu og hæfni í ólíku samhengi.

- Ad taka mid af ólíku samhengi fyrir starfid.

- Aà nota tengslanet og tengsl.

- Aə hvetja til breytilegra samstarfsaðferða.

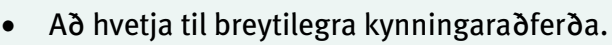

- Ad vekja til umhugsunar med tilliti til athafna.
${ }^{10}$ Verðmætasköpun greinir kennsluferli frumkvöðlamenntar frá öðrum ferlislægum kennsluaðferðum, til dæmis vandamálamiðaðri verkefnakennslu eða pemavinnu. Með verðmætasköpun er átt við að starfið skapi verðmæti fyrir aðra, fyrir utan nám nemendanna sjálfra.

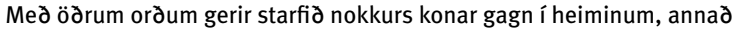
hvort sem ákveðið starf eða hugsanlega sem áform, líkön o.s.frv.

\section{Áherslur sem styðja aukna sköpunarhæfni}

- Ad vinna tilraunastarf.

- Ad skapa tíma án mats.

- Ad vinna skapandi starf.

- Ad tryggja tíma til íhugunar.

- Ad leggja fram opin/ómöguleg verkefni.

- Aa koma á óvart og koma á hinu óvænta.

- Ad láta mörg skilningarvit koma við sögu.

- Ad vekja til umhugsunar um hugmyndaflug og sköpunargleði. 


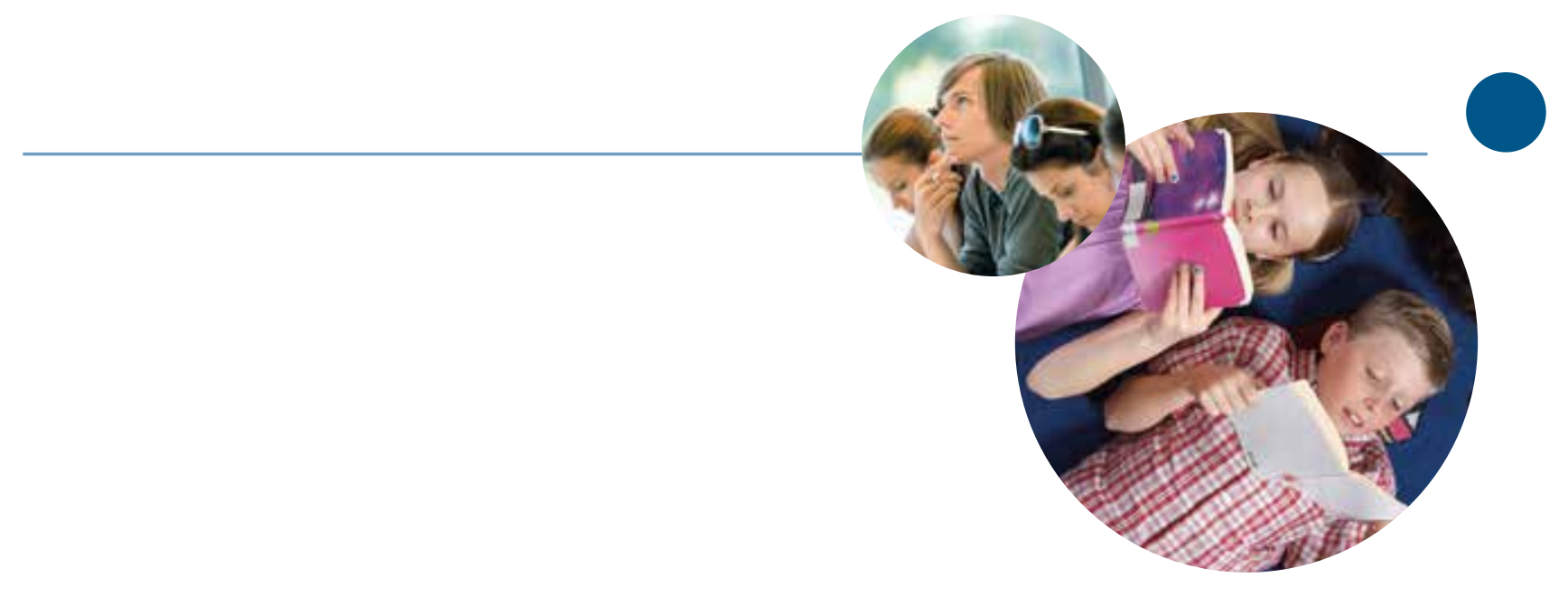

\section{Áherslur sem styðja aukinn skilning á umheiminum}

- Ad hvetja til forvitni og undrunar.

- Ad fjalla um málefni lídandi stundar.

- Ad setja fagmennsku, pekkingu og leikni í samhengi.

- Ad láta félagslega, efnahagslega og menningarlega pætti koma við sögu.

- Ad tryggja samskipti einstaklings, skóla og umhverfis.

- Ad leita uppi pekkingu og viðbrögd frá umhverfinu.

- Ad lýsa heiminum sem möguleika.

- a vekja til umhugsunar um umhverfi skólans.

${ }^{11}$ Nemendur eiga „ad vera á tánum - en ekki of lengi“ 


\section{Dæmi um notkun kennslufræðilegra áherslna}

Dæmin eru unnin af starfandi kennurum og hafa verið reynd í norrænum skólum. Námsgreinarnar og helstu hæfnisvid eru sótt í „,sameiginleg markmid“ kennslunnar. Námsferlin eru venjuleg námsferli, sem með notkun kennslufræðilegra áherslna auk faglegra markmiða styðja líka við aukna frumkvöðlahæfni.

\section{Fjölbreytt lífríki, 4. bekkur}

Í ferlinu koma líka við sögu fagleg markmið úr námsgreininni „Náttúra/Tækni“, par med talin hæfnisvidin „könnun“ og „samskipti“.

Ferlið hefst með kennslu um hugtakið fjölbreytt lífríki. Sídan eiga nemendur upp á eigin spýtur à kanna ólíka gagnagrunna um dýr og búsvædi peirra (áherslan á að leita uppi pekkingu og viðbrögd frá umhverfinu). ا kjölfarid skipuleggja nemendur og kennarinn saman stutta ferd (áherslan á pátttöku nemenda og aðild), par sem nemendur í litlum hópum fara á dýraveidar i næsta nágrenni (áherslan á à hvetja til forvitni og undrunar) med sérstöku tilliti til à pekkja búsvæði og dýralíf í næsta nágrenni (áherslan á ad láta samhengi koma vid sögu). Nemendur eiga sídan ad velja ákvedið dýr og gera faglega könnun, (áherslan á ad skapa rými fyrir íhugun) skissur og teikningar (áherslan á ad láta mörg skilningarvit koma við sögu) med tilliti til að útbúa faglega kynningu (áherslan á að vinna á meðvitaðan hátt með óvissu). Á meðan á kynningunum stendur eiga hinir nemendurnir ad hrósa og koma med tillögur að endurbótum og frekara starfi (áherslan á að skapa rými fyrir viðurkenningu). Í lokin eru ræddar hugmyndir um hvernig nemendur geta stuðlad að pví að tryggja fjölbreytt lífríki í sínu nánasta umhverfi (áherslan á ad lýsa heiminum sem möguleika).

\section{Húsgagn fyrir vini, 7. bekkur}

Í ferlinu koma fagleg markmið við sögu úr námsgreininni „Handverk og Hönnun“, par á medal hæfnisviðin „Úrvinnsla“, „Efni“ og „Hönnun“.

Nemendur fá pad verkefni að útbúa „húsgagn“ sem kemur sér vel pegar maður er med vinum sínum. Ferlið hefst með umræðum og fyrirlestri kennara um sögu húsgagna og addraganda og próun hönnunar, par sem húsgögn eru bæði nytjavörur, vörur og listaverk (áherslan á à setja fagmennsku, pekkingu og leikni í samhengi). Sídan eiga nemendur ad fara í heimsókn í húsgagnaverslun (gjarnan í alvörunni, til vara í sýndarverslun) og kanna ólíka hönnun, efni og eiginleika (áherslan á að leita uppi pekkingu og viðbrögð frá umhverfinu/áherslan á à tryggja samskipti einstaklings, skóla og umhverfis). Peir velja húsgagn med tilliti til ad lýsa pví skriflega (áherslan á ad nota pekkingu og leikni í ólíku samhengi). Í kjölfarid vinna nemendur ad pví að próa hugmyndir ad eigin húsgögnum út frá ramma, par sem húsgagnið á à mynda ramma um ad vera med vinum og að geta lært saman (áherslan á opin/ ómöguleg verkefni). Sídan útbúa nemendur líkön af húsgögnunum í ákveðnum stærðarhlutföllum (áherslan á að láta mörg skilningarvit koma við sögu) og gefa

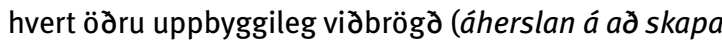
tíma án mats). Ad lokum eiga nemendur ad kanna, hvernig líkanið geti orðið að raunverulegri vöru og kanna, hvernig hægt er að skapa fyrirtæki á grundvelli framleidslu (áherslan á að vekja til umhugsunar med tilliti til athafna). Ad lokum útbúa og æfa nemendur söluræðu fyrir vöruna. 


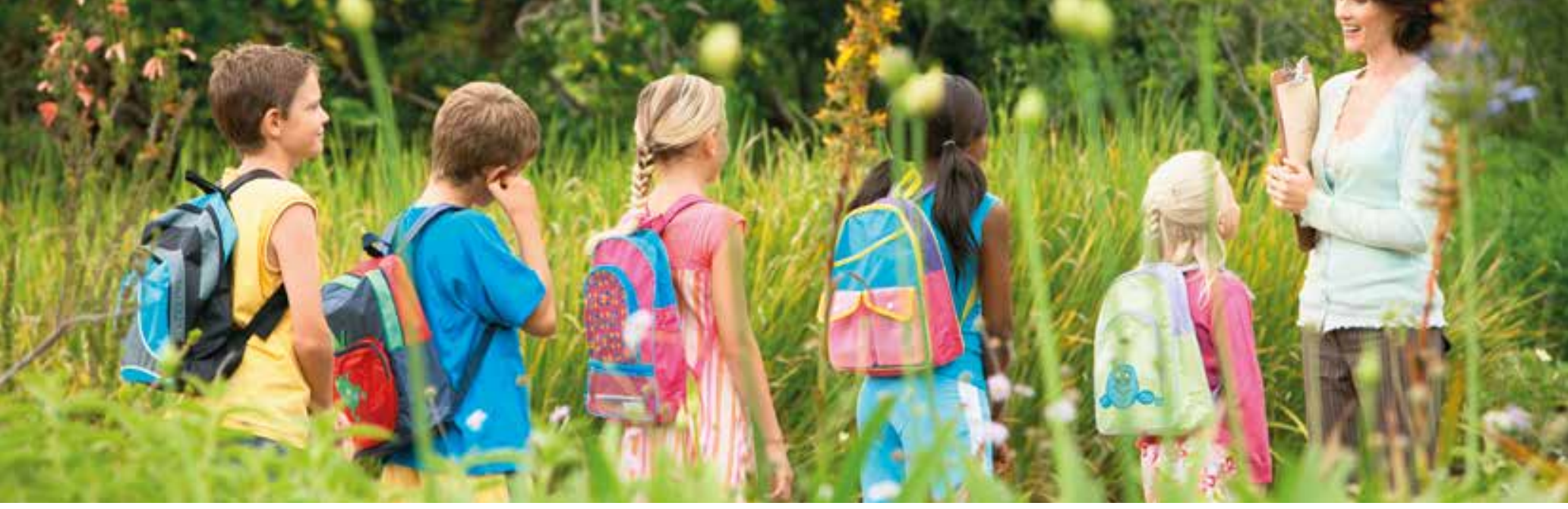

\section{Hagnýt stærəfræði, 8. bekkur}

Í ferlinu koma við sögu fagleg markmið fyrir námsgreinina stærðfræði, par með talið hæfnisviðið „stærðfrædihæfni“.

Í upphafi ferlisins er nemendum skipt í litla hópa og hver hópur fær hversdagslegan hlut, t.d. mjólkurfernu, hjól af reiðhjóli, glas, dagblað, afhent (áherslan á að koma á óvart og koma á hinu óvænta). Nemendum er sídan falið verkefni sem snýst um að ná eins mikilli stærðfræði og kostur er úr hlutnum sem pau fá í hendur (áherslan á à setja fram opin/ómöguleg verkefni, áherslan á aə vinna tilraunastarf), nemendur vinna à pví loknu sjálfstætt með verkefnið og kennarinn reynir á pau, gerir athugasemdir og styður nemendur á meðan (áherslan á aə leiðbeina og styðja).

Á grundvelli niðurstaðnanna útbúa nemendur stærðfræðidæmi sem peir láta aðra hópa fá, pannig að hóparnir skiptast á dæmum og hlutum. I lokin bera hóparnir saman niðurstöður sínar og útreikninga og gefa viðbrögd við vinnunni (áherslan á að skapa rými fyrir viðurkenningu).

\section{Auglýsingar, 10. bekkur}

Í ferlinu koma við sögu fagleg markmið fyrir námsgreinina dönsku, par á meðal hæfnisviðin „textagerd“, „túlkun“ og „samskipti“.

Í upphafi ferlisins eiga nemendur að kanna ákveðnar auglýsingar í nánasta umhverfi, taka myndir af peim og í kjölfarið greina pessar auglýsingar með faglegum líkönum og hugtökum og gera heildarmat á auglýsingum með tilliti til markhóps (áherslan á að hvetja til undrunar og forvitni). Nemendur eiga í kjölfarið að taka skipulegt viðtal við sendanda/fyrirtækið (áherslan á meðvitada óvissu). Að pessu loknu próa nemendur mismunandi tillögur (áherslan á að vinna tilraunastarf) að ödrum auglýsingum/fangamörkum fyrir hin greindu fyrirtæki (áherslan á að vinna með verðmætasköpun/ breytingastarf). I kjölfarið skal setja upp sýningu par sem nemendur kynna bekkingu og vörur fyrir fagmanni, sem leggur mat á vörurnar og lætur i ljósi álit sitt (áherslan á à tryggja tengsl milli einstaklings, skóla og samfélags). Ferlinu lýkur með sameiginlegum umræðum og vangaveltum um ferlið, samskiptin við umhverfið og faglegt nám (áherslan á à vekja til umhugsunar). 


\section{norden}

\section{Nordic Council of Ministers}

\section{Ved Stranden 18}

DK-1061 Copenhagen K

www.norden.org

Norræna rádherranefndin hefur unnið í mörgum áföngum að eflingu menningar og menntunar frumkvödla á Norðurlöndum. Hnattvæðing, tæknipróun, hraðar breytingar og lýðfræðilegar breytingar skapa áskoranir fyrir bæði norræna velferðarlíkanið og einstaklinga. Af peim sökum hefur i tímans rás komið fram pörf fyrir að menntakerfið geti undirbúið nemendur fyrir líf par sem peir geta verið virkir pátttakendur í mótun framtídar.

Verðlaunuð skýrsla Norrænu rádherranefndarinnar um

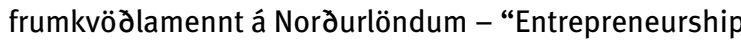
Education in the Nordic countries" - og skýrsla ESB um frumkvödlamennt - "Final Report of the Thematic Working Group on Entrepreneurship Education" - nefna pörfina á ad próa hæfniramma sem getur byggt brú milli stefnu, stjórnunar, starfsvenja og náms.

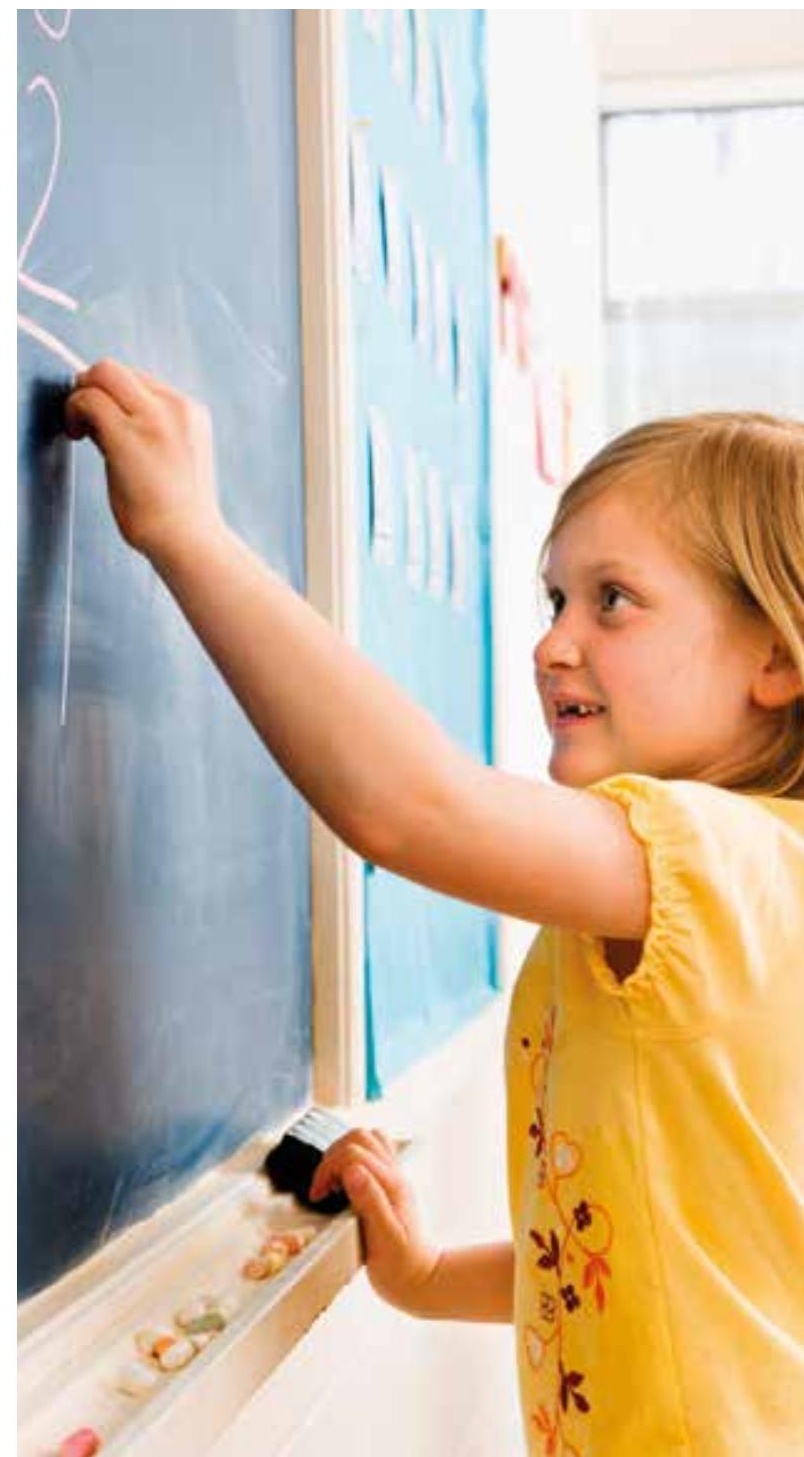

